\title{
Urban interventionism as a challenge to aesthetic order: Towards an aesthetic criminology
}

Andrew Millie

\section{Pre-publication version}

Published as:

Millie, A. (2016) 'Urban interventionism as a challenge to aesthetic order: Towards an aesthetic criminology', Crime, Media, Culture. Online First DOI: 0.1177/1741659016631609

\begin{abstract}
This article is concerned with ideas of urban order and considers the scope for playing with people's expectations of order. In particular, drawing on criminological, philosophical and urban studies literatures, the article explores the notion of aesthetic order. The power to dictate aesthetic order is highlighted. The example of urban interventionism is used to consider those that challenge an approved aesthetic order. Here the article draws on cultural criminology and visual criminology, with illustrations coming from research in Toronto, Canada. Influenced by Alison Young's (2014a) conceptualisation of 'cities within the city', the article considers how different people using the same space have different or overlapping ways of understanding aesthetic order. Of relevance to criminology, it is contended that people or things that contravene an approved aesthetic order may face banishment and criminalization. It is concluded that respect for such difference is required. An aesthetic criminology is suggested.
\end{abstract}

Key words: Aesthetic criminology, aesthetic order, disorder, order, urban intervention

\section{Introduction}

This article is concerned with the aesthetic order of the city. It considers the scope for playing with people's expectations of aesthetic order and the extent to which deviations are criminalized. The article draws on various urban studies, criminological and philosophical literatures and is illustrated using the example of urban interventions. The article draws on research conducted in Toronto, Canada during 2009. Toronto was one of the first places where the term 'urban intervention' was used in a 1999 gallery brochure for the Mercer Union Centre for Contemporary Art. 'Urban intervention' was used to describe artworks placed outside of traditional gallery spaces, but within broader urban contexts. In the gallery brochure Kym Pruesse described urban interventions as follows:

Most of the works I am speaking of are not advertised. They are not in gallery settings, not signed by artists, not for sale, and do not have arrows pointing to them screaming 'this is art!' That is part of their magic (1999: 9).

Urban interventions are performed amidst the normality of everyday urban existence. Important to Pruesse's description is the impromptu and maybe ephemeral nature of intervention. Currently, urban interventionism has increasing and diversifying prominence with the label applying to a broad array of activities (Brejzek, 2010; Brisman, 2010; Klanten and Huebner, 2010; Young, 2014a). Alongside street installations by 'traditional' artists, 
urban interventionism can also describe the work of graffiti writers and street artists, impromptu street performers, flash mobbers, parkour runners, mass participation cyclists, urban explorers, people who put up 'guerrilla stickers', guerrilla gardeners, guerrilla knitters or other urban activist and artistic groups. The activities of urban interventionists are of interest to criminology as they challenge directly the prevailing aesthetic order of the city using methods that are on the boundaries of normative acceptability and/or legality. The article contributes to understanding about relationships between aesthetics and order, and about different understandings of city living.

The term 'aesthetic order' was originally used by Ruth Lorand (2000) in her philosophy of order in beauty and art. For this article the phrase is used somewhat differently to reflect an expressed need for an orderly urban aesthetic. It is contended that the determination of aesthetic order is intrinsically political (cf. Ranciere, 2004), and that people or things that contravene an approved aesthetic order may face criminalization and banishment (cf. Beckett and Herbert, 2010).

The article draws on cultural criminology in considering the relative importance of resistance, risk taking and playfulness for urban interventions. In terms of criminological work on aesthetics, recent years have seen the emergence of a visual criminology (e.g. Brown, 2006; Ferrell, 2006; Hayward, 2009; Hayward and Presdee, 2010; Carrabine, 2012; Young, 2014b). This has drawn - at least in part - from cultural criminology in investigating the interplay between visual culture and criminological interest. But, just as cultural criminology is not restricted to the visual, visual criminology has not evolved solely from cultural criminology. That said, there is some significant crossover between these two criminologies. This article is influenced by both. The article suggests an aesthetic criminology is possible that includes consideration of the visual, but also broader sensory, affective and emotive experience.

No claims are made for Toronto being more suitable than other cities for such a study. That said, over the past few decades strong urban activist communities have grown across the city (e.g. Keenan, 2005). The City itself has emphasized urban beautification through its 'Clean and Beautiful City' and 'Beautiful Streets' programmes ${ }^{1}$. Those interviewed $(n=15)$ were an opportunistic sample of urban interventionists, police and city personnel and are not representative of all points of view (see also Millie, 2011). The quotes used are drawn from particularly prolific urban interventionists. They are included to illustrate discussion and it is acknowledged that other perspectives will certainly exist. All are anonymized.

The article draws on Alison Young's conceptualisation of 'cities within the city' (2014a: 48), with different people using the same space having different or overlapping ways of understanding city living, different conceptions of beauty, and of aesthetic order. Respect for such difference is seen as essential. In what follows the meaning of aesthetic order as applied to the urban context is considered, and the power to dictate an approved aesthetic order is highlighted. The example of urban interventionism is used to consider those that challenge an approved aesthetic order. Finally, an aesthetic criminology is proposed.

\section{Aesthetic order}

In 1971 a comedy routine was first aired on British television involving the comedians Eric Morecombe and Ernie Wise, the conductor André Previn and a full orchestra. In the routine Morecombe was chastised by Previn for playing the piano awfully. Morecombe's famous 
response was that "I'm playing all the right notes, but not necessarily in the right order". By playing with people's expectations the apparent disorder of Morecombe's piano playing made for a great gag.

In 1996 world famous jazz trumpeter Wynton Marsalis said as encouragement to a child musician, "Remember ... nothing you play is wrong. It's impossible to play anything that is wrong" (Glaister, 1996). For Marsalis, new expression and beautiful forms could be found through what others might perceive as disorder, that "nothing you play is wrong".

The philosophical study of aesthetics is most associated with arts appreciation, particularly concerning debates over what constitutes good or bad art. Such assessments are often tied to notions of good and bad taste. A Kantian perspective - and one that this article follows - is that taste is entirely subjective, that "an objective principle of taste is impossible" (Kant, 1790/2011: 12). Thus, questions concerning who has better taste than others are highly debatable. For instance, according to the conservative philosopher, Roger Scruton (2009: 133), "In a democratic culture people are inclined to believe that it is presumptuous to claim to have better taste than your neighbour. By doing so you are implicitly denying his right to be the thing that he is". Yet Scruton continues:

Your neighbour fills her garden with kitsch mermaids and Disneyland gnomes, polluting the view from your window; she designs her house in a ludicrous Costa Brava style, in loud primary colours that utterly ruin the tranquil atmosphere of the street, and so on. Now her taste has ceased to be a private matter and inflicted itself on the public realm (Scruton, 2009: 133-134).

The suggestion is that tastes matter when they are public. My counter argument questions who has the right to suggest a neighbour's tastes are inappropriate (see also Millie, 2014; 2016). Criminological and legal theory usually emphasize harm and offence as determinates of what is acceptable and what is criminalized (Feinberg, 1984; 1985; Hillyard et al., 2004; von Hirsch and Simester, 2006); yet taste also plays a part in shaping perceptions of harm and offence. Some tastes are almost universally regarded as harmful or offensive (and censurable), such as graffiti that is inflammatory, racist, sexist or homophobic, although normative views on insult clearly change through time. There are many other aspects of latemodern life that one may not like, but can be classed as differences of taste that ought to be tolerated rather than censured. Drawing on Pierre Bourdieu (1979/2010) a cultural aristocracy of taste can be traced from the seemingly 'legitimate' tastes of the ruling classes, down to middle-brow tastes and then to popular tastes. Those who have power to dictate 'legitimate' taste are those with requisite political and cultural capital. There may also be minority subpopular tastes that go against normative or majoritarian conceptions of acceptability (Millie, 2008; 2014); and, using Scruton's example, these might include having a garden full of gnomes and mermaids or a house designed in, "a ludicrous Costa Brava style". Using Jeff Ferrell's (1996) terms, such cultural aristocracy can be regarded as an aesthetics of authority. In Scruton's example, those with power might include potential property purchasers, real estate agents afraid of a negative impact on prices and local planning departments.

A contrast can be seen between the ordered city of planners and others with power, and a disordered city of everyday experiences (cf. de Certeau, 1984). However, such everyday experiences may be interpreted as disorderly simply because that is how they are constructed by those with power. For those living these experiences it is possible that they represent 
alternative visions of urban order (rather than disorder). What is important at this stage is that, in shifting discussion from arts appreciation to everyday experiences we have moved aesthetics into the territory of what Yuriko Saito (2007) has termed everyday aesthetics. Influenced by Henri Lefebvre's (1961/2008) 'everyday life', the focus is on everyday objects, events and encounters. In terms of urban interventionism, reading graffiti or encountering an illegally planted guerrilla garden are everyday aesthetic experiences. For such activities beauty may be in their unexpectedness and unpredictability, their apparent disorder.

Yet, for others, beauty is in certainty and predictability, in 'aesthetic order' (cf. Lorand, 2000). Bertrand Russell, for one, found beauty in the predictability of mathematics:

[Mathematics is] capable of an artistic excellence as great as that of any music ... because it gives in absolute perfection that combination, characteristic of great art, of godlike freedom, with a sense of inevitable density; because, in fact, it constructs an ideal world where everything is perfect and yet true (Russell, 1967: 158-159).

From this modernist perspective there is beauty in knowing that everything is true and in its correct place. Returning to Bourdieu (1979/2010), some may take comfort in thinking there is a strict progression of taste through to the legitimate tastes of the ruling classes. And, according to Scruton (2009: 80), "even vegetable patches have their aesthetic constraints, being arranged in rows and neatly spaced, so as to satisfy our need for visual order". Scruton further claims that, "gardens have their own distinctive phenomenology, in which nature is taken up, tamed and made obedient to human visual norms" (2009: 80). Informal as well as formal rules are created that dictate how an ordered garden ought to look.

Applying this idea to the urban landscape, the city is tamed and beauty is found in an ordered urbanity. It is a particular form of aesthetic order defined by those with power where spontaneity is replaced by predictability. In the late-modern west, the city becomes a machine to maximise movement and economic exploitation. For instance, according to Nicholas Blomley (2011: 39-41), for city engineers, "[t]he 'successful' sidewalk is one that separates and buffers, arranging people and objects so that collisions and encounters are minimized". Anything - or anyone - that challenges this logic is deemed out of place (cf. Cresswell, 1996) and may be criminalized or banished.

Of course, to suggest the city should be strictly ordered is problematic, as urban spaces are also sites for amazement, spontaneity and carnival (Presdee, 2000). And other ideas for less segregated sidewalk living have been promoted - most notably by Jane Jacobs (1961). Nonetheless, cities are governed by normative and criminal/municipal rules - from litter bylaws to zoning ordinances - with the aim of creating everyday order, with everything in its rightful place and adhering to aesthetic norms (see e.g. Valverde, 2012). According to Young (2014a: 43), this is the 'legislated city' where attempts to order the city are "based on a desire to control the city's perceived unruliness and fecklessness". Rules governing acceptability are created by those with power, and in the late-modern neoliberal city the powerful are most often civic and commercial (often retail or landowning) interests that dictate the look and feel of cities. This is not to say that economic exploitation is always foregrounded in urban planning, marketing and city centre management, with various cultural and amenity benefits also being promoted. However, by promoting approved cultural practices for specified locations and times, the 'feel' and vibrancy of the city are 'improved' in ways that have the aim of achieving economic benefit. There are consequences for anyone whose cultural 
practices are not thought to benefit the economy, and such activities are often seen as 'broken windows' to be fixed. For instance, across London there are designated pitches for busking, some of which require auditions. In order to busk on the London Underground prospective buskers have to face an X-Factor style audition ${ }^{2}$. Anyone not permitted, or performing in the wrong location, is likely to be regarded as an incivility to be moved on.

While there can be beauty in an orderly aesthetic, there is also beauty in apparent disorder. The geographer and social theorist Yi-Fu Tuan (1993) highlights that 'aesthetic' is opposite to 'anaesthetic'. In other words, it is associated with feeling alive, and feeling alive is seldom about perfection. According to Tuan:

...the pervasive role of the aesthetic is suggested by its root meaning of 'feeling' - not just any kind of feeling, but 'shaped' feeling and sensitive perception. And it is suggested even more by its opposite, anaesthetic, 'lack of feeling' - the condition of living death. The more attuned we are to the beauties of the world, the more we come to life and take joy in it (Tuan, 1993: 1).

True, some may find joy in neat rows of vegetables, in the predictability of mathematics formulae, or in neatly ordered cities; but it is also found in unpredictability - the kind of joy expressed by Morecombe and Wise, and by Marsalis's jazz. This is also the joy of urban interventionism, the kind of activities that Ferrell has described as an "impassioned assault" on modern boredom (2004: 292). Through alternative performances of aesthetic (dis)order, urban interventionists challenge our understandings of order and acceptability.

The city can be regarded as composed of people rather than a collection of buildings and services - in the same way that many Christians view their church as the people rather than the building. Buildings and services, and other tangible 'things', are clearly important to a city (and to a church), but without a population - or congregation - we are left with empty buildings, a metro with no passengers, or a shopping centre without any shoppers. Without any people, what is left is no longer a city. The city is born through people's dealings with each other, through their imagination and their interaction with the city's various 'things'. According to Jonathan Raban (1974) cities are soft places: "We mould [cities] in our images: [but] they in turn, shape us by the resistance they offer when we try to impose our own personal form on them" (Raban, 1974: 10). From Raban's perspective the city resists attempts at forcing order - and this includes attempts made by powerful interests trying to impose aesthetic order to maximise economic gain. But if the city is the people, then this resistance comes from city dwellers with alternative visions for their city. Such people includes urban interventionists and it is to these that I now turn. Their resistance is conceptualised as a subversion of legal and aesthetic urban order that operates, by the very nature of the activity itself, with or without intention. Drawing on Young, (2014a) not everyone would be delighted by such challenges to urban order. Yet Young notes the importance for citizens to recognise "the existence of other ways of being ... indeed other cities and their inhabitants" (p48, original emphasis). Young talks in terms of "cities within the city" (p48); that people using the same space can understand the city in different or overlapping ways. It is a useful idea that fits with the notion of cities as the people (rather than simply as a grouping of buildings and services). For Young, there are 'uncommissioned cities' that coexist with the 'legislated city'. These uncommissioned cities are the domain of urban interventionists. 


\section{Urban interventionism}

As noted, Pruesse (1999) was one of the first to describe urban interventions while writing in a Mercer Union gallery brochure in Toronto. In fact, Mercer Union had promoted similar works in the late 1970s and early 1980s. For instance, a 1980 Mercer Union catalogue described the ambiguous legality of some of their works positioned around the city:

For the artists there are challenges in finding and securing locations in a city of suspicious landlords and nervous politicians. [The artist] Robert Bowers decided to rent a spot in the parking lot beside his studio while others approached City Hall seeking permission to use vacant city-owned property. Still others chanced endurance by locating their pieces without securing any permission whatsoever. Unsolicited alteration and removal of works last year was not uncommon (Hill and Balfe, 1980).

The Mercer Union works may also have been at home within a traditional gallery setting. It was their removal from the gallery and the changed spatial and temporal context that made them challenging. The renting of a parking spot to temporarily 'install' an artwork was particularly innovative - and was an idea more recently reinvented by Philip, one of the urban interventionists I interviewed in Toronto. Philip had used on-street parking to host a protest picnic and croquet match, complete with fake grass:

...looking at how our city works and how the automobile is so omnipresent in our North American culture I just thought it'd be fun to do sort of a good deed one day, good deed for the world. And me and some friends got together and we took over all the parking spots on the street ... the idea was oh let's throw a party, let's feed the meter, and reclaim that space. For about fifteen hours you can rent a six by twelve foot parking spot and, instead of just parking a car there, you could have all sorts of other activities go on.

There was some initial confusion from the police, but no real trouble: "sure enough a police officer came. 'What are you guys doing?' 'We're feeding the meter, don't worry'. ... He laughed his head off. He said, 'this is hilarious, like, have fun"'. Young (2014a: 104) has similarly found that police officers can display aesthetic judgment about the graffiti and street art seen on the street. It seems officer taste and aesthetic judgment can apply to a range of urban interventions. For Philip, the fun of the intervention was important, but so too was the political message. He cited the Situationists as an influence:

I love the Situationists and I love the idea of bringing art and humour into protest instead of the angry yelling placards sort of thing ... What we'll do in a parking spot is roll out Astroturf and set up a croquet pitch and play croquet, dressed jaunty and have a picnic in top hats and tails. ... it is absurd, it is ridiculous. And it's absurd and ridiculous that people are making cars bigger and bigger ... to take up that much public space with that much metal when, you know, it should be everybody's space.

When I interviewed Philip the most recent intervention was the creation of a planter made from a wrecked car, that was 'parked' on a street in Kensington Market and the meter paid. Such activities push the boundaries of legal and normative acceptability and what is regarded as ordered and disordered. Initially the police had the car towed away, but the City Council eventually gave permission; as Philip put it, "City Council said, okay you can keep it as 
public art, but it's got to be removed for the snow clearing season". It is possible the City Council gave permission only because it was in Kensington Market, a district known for alternative cultures where a car planter may have been a further attraction for tourists - who would hopefully spend more money in the area. In a more affluent district the car may have been too much of an aesthetic challenge. Some urban geographers have written about moral geographies of public space (e.g. Smith, 1997; McAuliffe, 2012). It is possible that moral geographies work alongside economic and prudential (quality of life) geographies - as well as aesthetic geographies - in dictating what becomes acceptable, where and when, and what becomes censured (see also Millie, 2011). Yet, even within Kensington Market such activities are not welcomed by all. According to Misha Glouberman (2005: 126-127) a related initiate to create a car-free Kensington Market ${ }^{3}$ risked damaging the uniqueness of the district:

What makes Kensington great is the mix of all different sorts of people going about their lives. It's a fantastic bustle of people of tremendously varied ages, classes and ethnicities, all engaged in the day-to-day business of real life. Festival Sundays replaced that real life with rock bands, sidewalk DJs, huge crowds and street performers.

The apparent disorder of 'real' street life followed its own rules of everyday existence and, in that sense, could be said to be ordered - or to use Milovanovic's (1997) terms, it had orderly disorder. This was replaced by a new (dis)order characterised by street entertainment and pedestrianisation. According to Glouberman the new party aesthetic led to gentrification: "every year a couple more grocery stores and spice shops close, and someone opens another upscale restaurant or café or skateboard shop" (2005: 129) ${ }^{4}$. This is a common issue that has been identified in gentrification literature (e.g. Smith, 1996; Lees et al., 2008; Zukin and Braslow, 2011).

Such urban interventions are not new and similar activities occur in other cities across the world. For instance, in the US during the 1980s (Dery, 1993) - and later spreading elsewhere (Brisman, 2010; 2013) - were the overtly political actions of 'culture jammers'. Influenced by Umberto Eco's (1973) call for semiological guerrilla warfare, culture jammers aimed to create interference between the transmitters and receivers of media messages. One way to achieve this was through 'subvertising', "the production and dissemination of anti-ads ... illegal, late-night sneak attacks on public space by operatives armed with posters, brushes, and buckets of wheatpaste" (Dery, 1993). During the late 1970s and 1980s in Australia, a similar approach was adopted by BUGA UP, the 'Billboard-Utilizing Graffitists Against Unhealthy Promotions' (Chapman, 1996; Iveson, 2013), who added graffiti to tobacco and alcohol billboard advertising in order to change the message and emphasise the products' danger to health. More recently a sophisticated version of this approach was adopted in Britain by the Cut Up collective who would take down advertising posters that were then cut into pieces and re-applied, creating new - often revolutionary - images (see Mathieson and Tàpies, 2011). According to the collective:

Our definition of play is to deliberately break the rules and invent our own, thus freeing creative activity from restrictions, to redesign aesthetic and revolutionary actions that undermine or elude social control (Cut Up collective, cited by Seventeen Gallery, 2006). 
Similar interventions occur in other cities, such as Toronto, New York and Madrid, as detailed by the Public Ad Campaign ${ }^{5}$. Also, in the UK, from 2012 onwards have been the activities of Brandalism, where advertising posters have been illegally replaced by artworks. According to the Brandalism website (accessed 2015) ${ }^{6}$ :

Following on in the guerilla [sic] art traditions of the 20th Century and taking inspiration from Agitprop, Situationist and Street Art movements, the Brandalism project sees artists from around the world collaborate to challenge the authority and legitimacy of commercial images within public space and within our culture.

A way to view such urban interventionism is through the lens of cultural criminology, including consideration of edgework's emphasis on resistance, voluntary risk taking and playfulness (Lyng, 1990; Presdee, 2000; Hayward 2004; Hayward and Young, 2004). The examples cited thus far include all three elements. Yet playfulness is of central importance for urban interventions, what Christopher Williams (2007: 49) sees as 'playful criminality', or what Avi Brisman (2010) recognises as 'creative crimes'. Drawing on the work of Naomi Klein (1999), Brisman (2010) highlights how criminology may have focused on 'hard-core revolutionary' acts to the detriment of playfulness, or what he terms 'merry pranks':

Direct action and civil disobedience are well within the purview of criminology ... But somewhat subconsciously, criminology has distinguished between what Klein (1999: 283) refers to as 'hard-core revolutionary' acts and 'merry pranks,' with the former constituting an arena of inquiry ... and the latter largely omitted (Brisman, 2010: 206).

This playfulness is apparent in historic examples such as the culture jammers and BUGGA UP and Cut Up collectives already mentioned. Clearly political messages are important, but so too is humour. The Toronto interviewee mentioned above claimed the Surrealists as an inspiration, and all urban interventions can, to a greater or lesser extent, be said to be influenced by the "avant-garde artistic agitation" (Plant, 1992: 1) of the Situationists, Surrealists and Dadaists, for whom playfulness was an important consideration alongside any political message. Early examples of urban interventionists include the 1960s San Francisco Diggers, an "anarchist guerrilla street theater group" (The Digger Archives, 2013). Similarly during the 1960s the Amsterdam Provos initiated their famous white bicycle plan leaving free-use bicycles around the city. Both the Diggers and the Provos displayed political and playful ambitions. For instance, according to Hans Pruijt (2004: 232), the Provos were "mixing art and politics, defying the ruling powers and the police, developing playful alternative plans".

Another example of urban interventionism in Toronto is the work of the cycling movement Critical Mass, a group described by Ferrell (2004: 292) as, "[a] rolling mix of bicycle activists and cultural revolutionaries" (see also Carlsson, 2002; Furness, 2010). Each month a mass cycle ride is held in Toronto, much the same as occurs in many other cities around the world (see Figure 1). 


\section{Figure 1. Critical Mass cycle ride through Toronto}

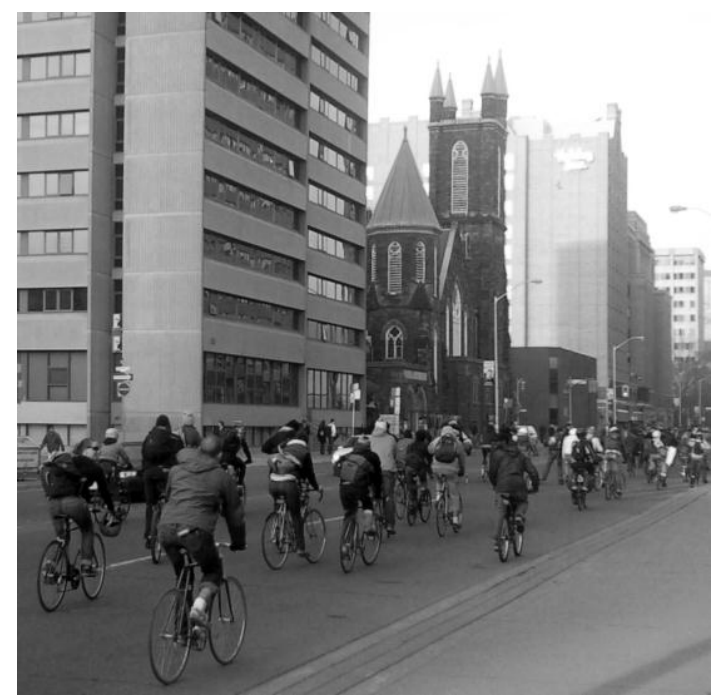

Photo by the author

Motivations vary depending on participant - ranging from political resistance through to having a nice trip out with safety in numbers. Philip cited an example that had occurred the year before when the police got involved in a ride, when Critical Mass took on an urban motorway:

... we were riding past the on-ramps to the Gardiner [Expressway] and one person kind of rode up as a joke and looked around and ha ha ha. Next thing you know, oh my God, we're on the on-ramp, there's four hundred cyclists. And we had a little huddle at the top, going 'okay are we really going to do this?' ... Next thing you know, we're on the highway and spread out into all four lanes of the highway, there were four hundred cyclists riding on the Gardiner. ... I love that about Critical Mass too, to me that's like one of those wacky, absurd, zeitgeist moments ... And sure enough you know, the police were not happy about that.

The cyclists' actions could be seen as the kind of "impassioned assault" on modern boredom that Ferrell describes (2004: 292); yet they could also be regarded as highly irresponsible with children among those cycling on the motorway - as seen on You Tube coverage of the event ${ }^{7}$. According to one interviewee, Charles, "We should've gotten off before it got out of hand, but nada. People got happy. They had such a good time, you know". Critical Mass cycle rides are usually more mundane, normally "just a ride around town" (Charles); but with any mass intervention there may be some more willing to push boundaries. Internationally different rides have hit trouble. For example, on one day in August 2004 New York police are said to have made over 260 arrests during a Critical Mass ride that happened to coincide with a Republican Convention taking place in Manhattan (Keller, 2011). During the run up to the 2012 London Olympics over 130 arrests were made at one ride in London (BBC News, 2012a).

Another form of mass urban intervention is the 'flash mob', where "strangers come together in a public place, perform an unusual behavior, and randomly disperse" (Duran, 2006: 301; 
see also Wasik, 2009a). The participants in flash mobs are brought together via email, text or other social media. Some of the more famous flash mobs originated with the New York group Improv Everywhere. It was Improv Everywhere who organised 'freeze' in Grand Central Station, New York in 2007 where those in the know suddenly stopped what they were doing and froze. According to the organisers of the event:

It must have been shocking for tourists and commuters to see hundreds of people hustling across the concourse one second and then, in a flash, see time stop for more than two hundred of them. When I saw the freeze happen, it looked like somebody hit the pause button on the DVD player. ... The eeriness of the situation was magnified by the dramatic silence that fell over the train station (Todd and Scordelis, 2009, 101).

Deborah Landry (2013: 3) has described the flash mob as "performative resistance to power and governance". To use the city's spaces in ways that are unexpected is a political act; yet for those involved such resistance can be unintentional - it is more about having fun, about being part of something exciting, or about making an artistic statement. Bill Wasik is credited with starting flash mobs in $2003^{8}$ with 'the mob project'. According to Wasik:

To me, flash mobs were a kind of performance art and, you know, they weren't protests, they certainly weren't a substitute for protest. They were a social experiment, they were a demonstration of what the technology of internet chain emails could do and text messaging can do and a demonstration of social networks (Wasik, 2009b).

That said, flash mob methodologies are utilised by more overtly political actors through various 'flash protests' and urban disorders 9 . In Toronto there are two main flash mob groups, New Mind Space and Improv in Toronto ${ }^{10}$. One of my interviewees, William, was involved in both. Following his suggestion I witnessed a mass pillow fight organised by New Mind Space at Dundas Square in the centre of Toronto's retail district (see Figure 2). This has since evolved into a global event taking place each year, with the 2014 pillow fight taking place in over 120 towns and cities around the world (although by 2015 this was down to 75$)^{11}$. There have been attempts to ban or restrict flash mobs due to their impact on public order, principally their inconvenience and clean-up costs; and for some municipalities there has been a "blurring [of] flash mobs with illegal raves and riots" (Landry, 2013: 3). According to William there were specific complaints about the pillow fights, "people using feathers in the pillows leaves a big mess". The Guardian newspaper has reported on an attempted crackdown following a mass pillow fight in San Francisco where, after it rained, "mountains of sticky feathers clogged municipal drains, flooding streets and business premises" (Burkeman, 2009). 


\section{Figure 2: Toronto pillow fight}

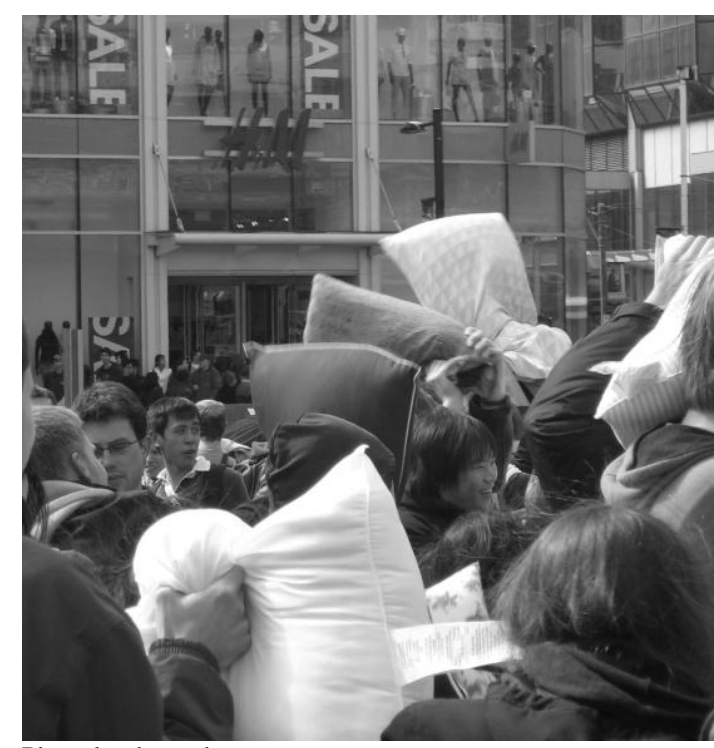

Photo by the author

Often for flash mobs no permission is sought as this is essential for (apparent) spontaneity, although for the Dundas Square event permission was sought and granted. For William this was a compromise: "I mean, there's all sorts of restrictions and they also have to pay a fee to book it ... which to me is ridiculous, I mean, it's not... for one, there's plenty of other places where you can do it for free, but it's no longer a spontaneous [event]". When asked about motivation for involvement William claimed that for him politics was part of it, but for most people it was about fun:

For me, it is a political thing. ... But I think for the average person, and if you look on their website and just the way people talk, it's entirely about having fun and getting people to question the everyday, I guess, you know, but yeah, they aren't very serious about that aspect of it. ... There's nothing remotely political at all.

Another flash mob that William had been involved in was a 'no-pants subway ride'. The original idea was in 2002 in New York by Improv Everywhere (Todd and Scordelis, 2009), when all those involved travelled on the subway in their underpants as if this was normal behaviour. In a similar event in Toronto participants danced to MP3 players whilst on the subway.

The final examples I use in this article can be characterised as illicit urban repair. During the first decade of the twenty-first century a group of three former art students were active in Toronto calling themselves the City Beautification Ensemble (CBE). Writing on the "Visible City' website, Eli Horwatt (no date) describes the CBE as "an urban interventionist group fighting against the dullness of the Toronto cityscape by introducing blocks of colour into the city". Again, this is an example of the kind of resistance against everyday boredom described by Ferrell (2004). Their main approach was to illegally spray paint city property - such as cycle stands and sidewalk slabs - with blocks of colour. According to a member of the ensemble, Jason Van Horne, their aim was to counter: 
...grey nausea which is, you know, [the] accumulation of all of the grey in blighted areas of the city ... Toronto is known I think for being a very dull, grey city, kind of very conservative and up tight in a lot of ways and so it is a very Toronto-based activity. We were able to sort of develop a, like, system of applying colours to certain areas of the city that would sort of offset those grey feelings (in Visible City, 2005).

This was a political, playful and artistic manifesto. For Van Horne the intervention's playfulness is reflected in the idea of pranksterism:

There is a big element of pranksterism to the work that we were doing, I mean going out in the middle of the night and trying to get away with something, you know, under the cover of the darkness (Van Horne, in Visible City, 2005).

Whilst clearly vandalism, according to another member of the ensemble, Duncan Walker, “...that what we were doing is wrong, it didn't feel like that at all” (Visible City, 2005).

The Urban Repair Squad has a similar mission - as summarised on their website: "They say city is broke. We fix. No charge" 12 (see also Toronto DIY Culture, 2012). Much of their activity is cycle focused and includes the illegal painting of 'guerrilla cycle lanes' or other cycle road markings. In this regard the current urban order is directly challenged and a new order (unlawfully) promoted. The idea is global and there are clear links to the Critical Mass movement. According to an interviewee in Toronto, Charles, "We started realising that the bike plan that the City started in 2001 basically went nowhere" (see City of Toronto, 2001). Despite promises for cycle provisions, little was forthcoming and so the group decided to paint cycle lanes themselves:

...it started out with smaller ones ... and then it just grew and people just started doing the middle of days in rush hour, dressed up as municipal workers and just put it in, right in the contra flow, right into the traffic, it's insane. And then went away that night, then we added more things to it. It's just kept sort of growing. We're up to about six kilometres now.

Many lanes have been erased, but some survived. The key was to do a good job: "They looked very professional, we did it really, really neatly, cleaned the street beforehand, they should last". Actions were again political and playful. For instance, in winter seats had been dug out of snow at tram stops; as Charles put it, "we'll like take piles of snow next to a $\mathrm{TCC}^{13}$ stop, we'll turn it into benches out of snow in the brutal cold so people can sit down when they're waiting for the street car". Another activity by the group has been the development of 'guerrilla stickers' to change the cycle restriction signage on the subway (see Figure 3). The specific sign that was targeted was a red circle highlighting that cycles were not permitted at certain times. The group replaced these with almost identical stickers, but with green circles with a cycle, highlighting the times that cycles are allowed:

Exactly the same but we just swapped it, from negative to positive. ... we did about two hundred and fifty stickers in one night. ... It was great. It worked out well, I mean there was about seventy stations, and three or four each ... I mean it's exactly the size, the same bylaw, the same logo, the same font, exactly the same. We had a designer do it for us, so it's exactly the same. And yeah, it was a correction. ... At every station, 
sometimes right on the collector's booths on the inside, right next to the guy who's collecting the cash, that was a little daring (Charles).

Figure 3. 'Bicycles allowed' guerrilla sticker in Toronto

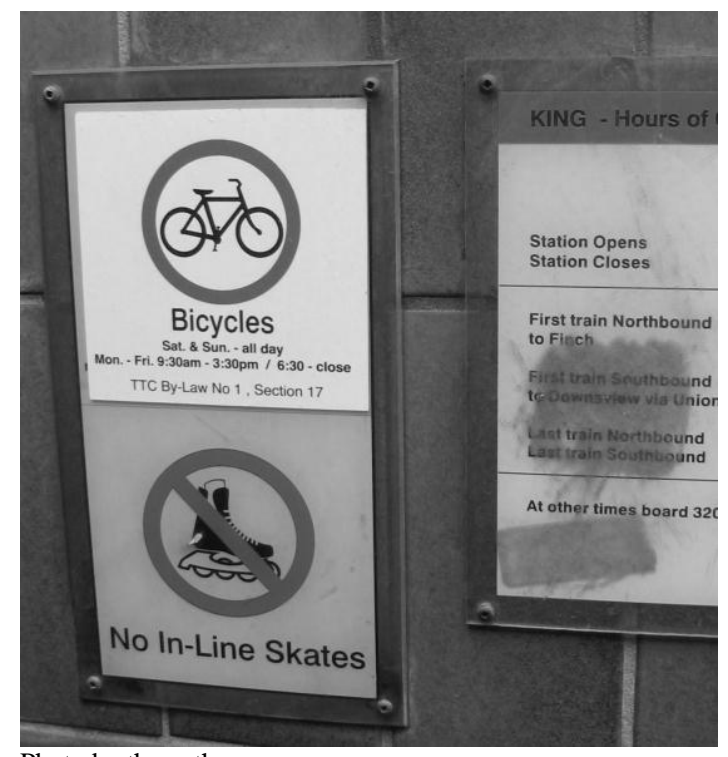

Photo by the author

Charles highlighted the risks involved: "that's the danger with any of this, that at any time they could come up with charging you with whatever they want. But, so far, our approach as opposed to other sort of activist groups has been that we try not to get caught really, at the moment". The use of 'guerrilla stickers' has since appeared elsewhere, including in London (BBC News, 2012b). These stickers are often mischievous rather than political (such as replacing a sign for 'Shepherd's Bush' underground station with 'Shepherd's Pie'). I asked Charles if there had ever had any problems with the police:

No-one's been caught. The police have gone by as we were doing it. ... Three cars went by, we were all like, we all froze like a little - you know rabbits in headlights. Never. Never been caught. Not even close. I mean we had one - we had some locals saying, 'what the hell are you doing?' And we usually tell them it's an art project. ... [or] we're just testing something out, you know.

\section{Discussion}

Aesthetic order in the city is often dictated by those with power. However, everyday experiences and perceptions of aesthetic order (and of what is acceptable) are essentially plastic in character. In this context the censure of activities that deviate from the approved aesthetic norm is never straightforward. For instance, an abandoned car filled with plants may be treated by the city authorities as an art installation in one district, but as a breach of highway law elsewhere. A mass cycle through the city's streets may be regarded as carnivalesque (cf. Presdee, 2000), until the cyclists move onto an urban expressway. A mass pillow fight might seem spontaneous fun, but to have it in a prime retail district requires planning, permissions, payment and control. The illegal painting of cycle lanes may go 
unnoticed in one district, but may draw the attention of the police in more commercially sensitive areas.

The late-modern neoliberal city demands planning and predictability in a similar vein to the neat rows of vegetables described by Scruton (2009). Integral to this is an assumed need for aesthetic order. For Young (2014a: 43) this is the 'legislated city'. In line with Tuan (1993), this article has argued that the aesthetic is also associated with feeling alive. While some may find joy in neatly ordered cities, there is also pleasure in unpredictability - the joy expressed by Morecombe and Wise, in Marsalis's jazz, and by urban interventionism.

Influenced by cultural criminology, the article has highlighted the importance of resistance, voluntary risk taking and playfulness for those who challenge the approved aesthetic order of the city. Of these, a chief aim for urban interventionism is often to play with people's expectations. The article has also been influenced by the recent emergence of visual criminology. The visual is clearly an important element of aesthetic experience, and central to many activities by urban interventionists. However, this interest could be expanded to an aesthetic criminology. This is not to say that visual criminology has got it wrong; rather, it is to highlight that there are broader sensory, affective and emotive experiences that could be of interest to criminology. An aesthetic criminology would be a new orientation that draws on both visual and cultural criminologies. It would not replace them, but would supplement the important work being carried out under those labels. In her study of everyday law in Toronto, Mariana Valverde (2012: 77) notes how municipal law:

... actively regulate[s] taste and culture ... by banning certain sights and sounds and smells but also ... by using law to compel people to maintain aesthetic standards.

An aesthetic criminology would be concerned with all these "sights and sounds and smells", as well as with emotive and affective responses to sensory encounters. It would similarly be interested in the regulation of tastes (e.g. Millie, 2008, 2014; Young, 2005, 2012; 2014a; Valverde, 2012). Urban interventionists, for example, do not solely challenge the visual, but make people think about the broader aesthetic experience of city living.

As noted, Alison Young has described city living as "cities within the city" (2014a: 48), that the same space can accommodate different groups of people with different and overlapping ways to understand urban life. There is the official 'legislated city', where aesthetic order is promoted by those with power, often influenced by neoliberal imperatives to consume and make money. Below this are various uncommissioned cities, including those promoted by urban interventionists. Where the interests of different 'cities' collide, there is the possibility of criminalization and censure. Alternatively, Jacobs (1961: 50) famously described city life as a sidewalk ballet, not "a simple-minded precision dance", but instead "an intricate ballet in which the individual dancers and ensembles all have distinctive parts which miraculously reinforce each other and compose an orderly whole". It is an appealing image; but rather than being an 'intricate ballet', contemporary city life is often composed of different dances and dancers which may or may not work together. In line with Young's idea of 'cities within the city', these different dancers may also conceive of the stage quite differently. For instance, a member of Critical Mass or the Urban Repair Squad will see the city as somewhere for free and safe movement by cyclists. A flash mobber will see the city as a stage for performing "extraordinary pranks in ordinary places" (Todd and Scordelis, 2009). The graffiti writer or street artist will regard the city as an endless canvass; for the free runner or parkour enthusiast 
the city is an outdoor gym with possibilities to explore. Using Young's terminology, problems occur when these different 'dances' being performed in different 'uncommissioned cities' conflict with those of the legislated city.

Each vision of the city has its own conception of (aesthetic) order; however, city living is about appreciating such alternative ways of being and respectful encounter with such difference (Millie, 2009) - so long as such difference does not unduly impact on others. It is the kind of mutual respect championed by Sennett (2003). But respect does not mean all doing the same as an (orderly) whole. Instead, there is room for a little uncertainty. There is scope for different interpretations, a little disorder, a "certain anarchy" (Sennett, 1970: 108). There is space to play the right notes "but not necessarily in the right order". There is even the possibility to redefine what constitutes a note.

\section{Acknowledgments}

The interviews were conducted whilst I was a Visiting Fellow at the Centre of Criminology, University of Toronto (now the Centre of Criminology \& Sociolegal Studies). I would like to thank all at the Centre, but in particular Mariana Valverde and Ron Levi. I would also like to thank all those I interviewed, as well as the reviewers for their helpful comments.

\section{Funding Acknowledgement}

The research in Toronto was funded by a Canada-Europe Award granted by the International Council for Canadian Studies.

\section{References}

Baker, S.A. (2011) 'The Mediated Crowd: New Social Media and New Forms of Rioting', Sociological Research Online, 16(4). Available at: www.socresonline.org.uk/16/4/21.html [Accessed 14 October 2015].

BBC News (2012a) 'Arrests in Critical Mass bike ride near Olympic Park', BBC News Online, 28 July, Available at: www.bbc.co.uk/news/uk-england-london-19023104 [Accessed 14 October 2015]

BBC News (2012b) 'Guerrilla stickers appear on Tube', BBC News Online, 10 October, Available at: www.bbc.co.uk/news/uk-england-london-19895637 [Accessed 14 October 2015]

Beckett, K. and Herbert, S. (2010) Banished: The New Social Control in Urban America, New York: Oxford University Press.

Blomley, N. (2011) Rights of Passage: Sidewalks and the Regulation of Public Flow, Abingdon: Routledge.

Bourdieu, P. (1979/2010) Distinction: A Social Critique of the Judgement of Taste, translated by R. Nee, Abingdon: Routledge.

Brejzek, T. (2010) 'From social network to urban intervention: On the scenographies of flash mobs and urban swarms', International Journal of Performance Arts and Digital Media, 6(1) 111-124. 
Brisman, A. (2013) 'In the garden with 'creative crime': Kudzu and the third branch', in M.V. Jacobson (ed.) The Poetics of Crime: Understanding and Researching Crime and Deviance Through Creative Sources, London: Ashgate, pp.51-70.

Brisman, A. (2010) 'CCreative crime' and the phytological analogy', Crime, Media, Culture, 6(2) 205-225.

Brown, M. (2006) 'The aesthetics of crime', in B.A. Arrigo and C.R. Williams (eds.) Philosophy, Crime, and Criminology, Urbana and Chicago, IL: University of Illinois Press, pp.223-256.

Burkeman, O. (2009) 'Flash mobs face ban after pillow fight fiasco', The Guardian, 11 March, Available at: www.theguardian.com/world/2009/mar/11/pillow-fight-ban-sanfrancisco [Accessed 14 October 2015]

Carlsson, C. (2002) 'Cycling under the radar: Assertive desertion', in C. Carlsson (ed.) Critical Mass: Bicycle’s Defiant Celebration, Oakland, CA: AK. pp75-82.

Carrabine, E. (2012) 'Just images: Aesthetics, ethics and visual criminology', British Journal of Criminology, 52(3) 463-489.

Chapman, S. (1996) 'Civil Disobedience and Tobacco Control: The Case of BUGA UP', Tobacco Control, 15, 179-185.

City of Toronto (2001) City of Toronto Bike Plan: Shifting Gears, Toronto: City of Toronto.

Cresswell, T. (1996) In Place - Out of Place: Geography, Ideology, and Transgression, Minneapolis, MN: University of Minnesota Press.

de Certeau, M. (1984) The Practice of Everyday Life, Translated by Steven F. Rendall, Berkeley, CA: University of California Press.

Dery, M. (1993) Culture Jamming: Hacking, Slashing and Sniping in the Empire of Signs, Westfield, NJ: Open Magazine Pamphlets, Available at:

http://project.cyberpunk.ru/idb/culture_jamming.html [Accessed 14 October 2015]

The Digger Archives (2013) 'Overview: Who were (are) the Diggers?' The Digger Archives, Available at: www.diggers.org/overview.htm [Accessed 14 October 2015]

Duran, A. (2006) 'Flash mobs: Social influence in the 21st century', Social Influence, 1(4) 301-315.

Eco, U. (1973) Faith in Fakes: Travels in Hyperreality, London: Vintage.

Feinberg, J. (1985) Offence to Others: The Moral Limits of the Criminal Law Volume 2, New York: Oxford University Press.

Feinberg, J. (1984) Harm to Others: The Moral Limits of the Criminal Law Volume 1, New York: Oxford University Press.

Ferrell, J. (2006) 'The aesthetics of cultural criminology', in B.A. Arrigo and C.R. Williams (eds.) Philosophy, Crime, and Criminology, Urbana and Chicago, IL: University of Illinois Press, pp.257-278.

Ferrell, J. (2004) 'Boredom, crime and criminology', Theoretical Criminology, 8(3) 287-302. 
Ferrell, J. (1996) Crimes of Style: Urban Graffiti and the Politics of Criminality, New York: Garland.

Furness, Z. (2010) One Less Car: Bicycling and the Politics of Automobility, Philadelphia, PA: Temple University Press.

Glaister, D. (1996) 'London youth impress jazz master Marsalis', The Guardian, 28 June, p2.

Glouberman, M. (2005) 'No place like Kensington', in J. McBride and A. Wilcox (eds.) Utopia: Towards a New Toronto, Toronto: Coach House Books, pp126-130.

Hartley, J. and Green, J. (2006) 'The public sphere on the beach', European Journal of Cultural Studies, 9(3) 341-362.

Hayward, K. (2009) 'Visual criminology: Cultural criminology-style', Criminal Justice Matters, 78, 12-14.

Hayward, K. (2004) City Limits: Crime, Consumer Culture and the Urban Experience, London: Glasshouse Press.

Hayward, K. and Presdee, M. (2010) Framing Crime: Cultural Criminology and the Image, Abingdon: Routledge.

Hayward, K. and Young, J. (2004) 'Cultural criminology: Some notes on the script', Theoretical Criminology, 8(3) 259-273.

Hill, P. and Balfe, M. (1980) Locations: Outdoor Works by Toronto Artists, Toronto: Mercer Union, Available at: www.mercerunion.org/exhibitions/locations-ii [Accessed 14 October 2015]

Hillyard, P., Pantazis, C., Tombs, S. and Gordon, D. (eds.) (2004) Beyond Criminology: Taking Harm Seriously, London: Pluto Press.

Horwatt, E. (no date) City Beautification Ensemble, Visible City Project + Archive, Available at: http://visiblecity.ca/index.php/interventions/74-city-beautification-ensemble [Accessed 14 October 2015]

Iveson, K. (2013) 'Cities within the City: Do-It-Yourself Urbanism and the Right to the City', International Journal of Urban and Regional Research, 37(3) 941-956.

Jacobs, J. (1961) The Death and Life of Great American Cities, New York: Vintage Books.

Kant, I. (1790/2011) 'Extracts from "Analytic of Aesthetic Judgment" and "Dialectic of Aesthetic Judgment", Critique of Judgment,' in Clive Cazeaux (ed.) The Continental Aesthetics Reader, Second Edition, Abingdon: Routledge, pp3-39.

Keenan, E. (2005) 'Making a scene: A bunch of youngish indie rockers, political activists and a small-press literati are creating the cultural history of Toronto', in J. McBride and A. Wilcox (eds.) Utopia: Towards a New Toronto, Toronto: Coach House Books, pp. 22-35.

Keller, L. (2011) Triumph of Order: Democracy and Public Space in New York and London, New York NY: Columbia University Press.

Klanten, R. and Huebner, M. (2010) Urban Interventions: Personal Projects in Public Places, Berlin: Die Gestalten Verlag.

Klein, N. (1999) No Logo: Taking Aim at the Brand Bullies, New York: Picador.

Landry, D. (2013) 'Are we human? Edgework in defiance of the mundane and measurable', Critical Criminology, 21(1) 1-14. 
Lees, L., Slater, T. And Wyl, E. (2008) Gentrification, Abingdon: Routledge.

Lefebvre, H. (1961/2008) Critique of Everyday Life, Introduction. Volume 1, translated by John Moore, London: Verso.

Lorand, R. (2000) Aesthetic Order: A Philosophy of Order, Beauty and Art, Abingdon: Routledge.

Lyng, S. (1990) 'Edgework: A social psychological analysis of voluntary risk taking', American Journal of Sociology, 95(4) 851-886.

Mathieson, E. and Tàpies, X.A. (2011) Street Artists: The Complete Guide, London: Graffito Books.

McAuliffe, C. (2012) 'Graffiti or street art? Negotiating the moral geographies of the creative city’, Journal of Urban Affairs, 34(2) 189-206.

Millie, A. (2016 forthcoming) Philosophical Criminology, Bristol: Policy Press.

Millie, A. (2014) 'The aesthetics of anti-social behaviour', in S. Pickard (ed.) Anti-Social Behaviour in Britain: Victorian and Contemporary Perspectives, Basingstoke: Palgrave Macmillan, pp. 102-111.

Millie, A. (2011) 'Value judgments and criminalization', British Journal of Criminology, 51(2) 278-295.

Millie, A. (2009) 'Respect and city living: Urban contest or cosmopolitanism?' in A. Millie (ed.) Securing Respect: Behavioural Expectations and Anti-Social Behaviour in the UK, Bristol: Policy Press, pp. 193-215.

Millie, A. (2008) 'Anti-social behaviour, behavioural expectations and an urban aesthetic', British Journal of Criminology, 48(3) 379-394.

Milovanovic, D. (1997) Chaos, Criminology, and Social Justice: The New Orderly (dis)order, Westport, CT: Praeger Publications.

Plant, S. (1992) The Most Radical Gesture: The Situationist International in a Postmodern Age, London: Routledge.

Presdee, M. (2000) Cultural Criminology and the Carnival of Crime, London: Routledge.

Pruesse, K. (ed.) (1999) Accidental Audience: Urban Interventions by Artists, Toronto: offlsite collective.

Pruijt, H. (2004) 'The impact of citizens' protest on city planning in Amsterdam', in L. Deben, W. Salet and M-T. van Thoor (eds.) Cultural Heritage and the Future of the Historic Inner City of Amsterdam, Amsterdam: Aksant Academic Press. pp.228-244.

Raban, J. (1974) Soft City, London: Hamish Hamilton.

Ranciere, J. (2004) The Politics of Aesthetics, London: Bloomsbury.

Russell, B. (1967) The Autobiography of Bertrand Russell, 1872-1914, Toronto: McClelland and Stewart.

Saito, Y. (2007) Everyday Aesthetics, Oxford: Oxford University Press.

Scruton, R. (2009) Beauty, Oxford: Oxford University Press.

Sennett, R. (2003) Respect: The Formation of Character in an Age of Inequality, London: Penguin. 
Sennett, R. (1970) The Uses of Disorder: Personal Identity and City Life, New York: W.W. Norton.

Seventeen Gallery (2006) Cut Up, Out of the Ruins of the Real..., Available at: www.seventeengallery.com/exhibitions/cut-up-out-of-the-ruins-of-the-real/ [Accessed 14 October 2015]

Smith, D.M. (1997) 'Geography and ethics: A moral turn?’ Progress in Human Geography, 21(4) 583-590.

Smith, N. (1996) The New Urban Frontier: Gentrification and the Revanchist City, London: Routledge.

Todd, C. and Scordelis, A. (2009) Causing a Scene: Extraordinary Pranks in Ordinary Place with Improv Everywhere, New York: William Morrow.

Toronto DIY Culture (2012) Ideas for Reclaiming Cities from Cars, Available at www.urbanrepairs.blogspot.co.uk/2014/08/toronto-diy-culture-review.html [Accessed 14 October 2015]

Tuan, Y-F. (1993) Passing Strange and Wonderful: Aesthetics, Nature, and Culture, Washington DC: Island Press.

Valverde, M. (2012) Everyday Law on the Street: City Governance in an Age of Diversity, Chicago, IL: University of Chicago Press.

Visible City (2005) Interview with Jason Van Horne and Duncan Walker (City Beautification Ensemble) June 6, Visible City: Project + Archive, Available at:

http://visiblecity.ca/index.php/interventions/74-city-beautification-ensemble [Accessed 14 October 2015]

von Hirsch, A. and Simester, A.P. (2006) Incivilities: Regulating Offensive Behaviour, Oxford: Hart Publishing.

Wasik, B. (2009a) And Then There's This: How Stories Live and Die in Viral Culture, New York: Viking.

Wasik, B. (2009b) Bill Wasik Introduces Flash Mobs, Bigthink.com, 2 July, Available at: http://bigthink.com/videos/bill-wasik-introduces-flash-mobs [Accessed 14 October 2015].

Williams, C.R. (2007) 'Potential spaces of crime: The playful, the destructive, and the distinctively human', Crime, Media, Culture, 3(1) 49-66.

Young, A. (2014a) Street Art, Public City: Law, Crime and the Urban Imagination, Abingdon: Routledge.

Young, A. (2014b) 'From object to encounter: Aesthetic politics and visual criminology', Theoretical Criminology, 18(2) 159-175.

Young, A. (2012) 'Criminal images: The affective judgment of graffiti and street art', Crime, Media, Culture, 8(3) 297-314.

Young, A. (2005) Judging the Image: Art, Value, Law, London: Routledge.

Zukin, S. and Braslow, L. (2011) 'The life cycle of New York's creative districts: Reflections on the unanticipated consequences of unplanned cultural zones', City, Culture and Society, 2(3) 131-140. 


\section{Author biography}

Andrew Millie is Professor of Criminology at Edge Hill University, UK. His work explores intersections between criminology, philosophy and urban studies. He is also interested in the relevance of theology to criminology. Andrew is the author of Philosophical Criminology (forthcoming) published by Policy Press.

\footnotetext{
${ }^{1}$ See e.g.

www1.toronto.ca/wps/portal/contentonly?vgnextoid=e8ab4074781e1410VgnVCM10000071d60f89RCRD [Accessed 14 October 2015]

${ }^{2}$ See https://tfl.gov.uk/info-for/media/news-articles/have-you-got-the-busk-fact, and buskinlondon.com [Accessed 14 October 2015]

${ }^{3}$ The interviewee Philip had been involved in the creation of car-free Sundays in Kensington Market

${ }^{4}$ For further examples of Glouberman's dislike of Toronto gentrification see Valverde (2012: 101-102)

${ }^{5}$ See http://daily.publicadcampaign.com/ [Accessed 14 October 2015]

${ }^{6}$ See www.brandalism.org.uk/the-project [Accessed 13 October 2015]

${ }^{7}$ See www.youtube.com/watch?v=c_jdkeOqGwY [Accessed 13 October 2015]

${ }^{8}$ See http://billwasik.com/post/104403795/the-mob-project [Accessed 13 October 2015]

${ }^{9}$ For instance, social media and mobile phone messaging were used in the 2005 Cronulla Beach riot in Australia (Hartley and Green, 2006) and, more recently, in the 2011 English riots (e.g. Baker, 2011).

${ }^{10}$ linked to the Urban Prankster Network See http://urbanprankster.com/ [Accessed 13 October 2015]

${ }^{11}$ http://2014.pillowfightday.com/ [Accessed 29 August 2014]; http://pillowfightday.com/ [Accessed 13 October 2015]

${ }^{12}$ See e.g. www.urbanrepairs.blogspot.co.uk [Accessed 13 October 2015]

13 Toronto Transit Commission
} 